may try to engage in false economy by employing inexperienced solicitors. This could prove disastrous.

For all these reasons, therefore, employing authorities may now be taking a more positive attitude towards looking for ways of reducing the risk of negligence actions. The apathy shown in the past by the Department of Health is indicated by the fact that until now authorities have not been required to report settlements under $£ 100000$. The new circular has put this right for the future. The most important step is to develop risk management procedures and medical audit. The BMA has repeatedly called for all medical audit to be funded by the NHS, but the department's response has been most unsatisfactory.

Another priority should be recognition of the need for doctors to explain to patients in appropriate cases the risks of therapeutic and diagnostic procedures when obtaining consent-and, even more important, to take the time to provide patients with an adequate explanation and to answer their questions when things have gone wrong. Recent reports of managers attempting to impose work "norms" on consultations suggest that the attitude of authorities towards profes- sional working practices will have to undergo a substantial change if the rapid increase in negligence actions is to be arrested.

Finally, doctors must clearly understand that the new circular applies only to services for which the employing authority is vicariously liable - that is, those that the doctor is required to carry out under his or her contract of service. There are several medical services carried out by hospital doctors that are not regarded as private practice but that will not be covered by the circular. They include category 2 work and voluntary attendance at accidents outside their hospitals. The defence bodies can be relied on to explain the position to any of their hospital members - including whole timers - who mistakenly believe that the circular provides an excuse for discontinuing their subscriptions.

J D J HAVARD

London N1 3DL

1 Anonymous. Legal actions involving hospital authorities and members of their medical staffs. Br.Med f 1954; i (suppl): 93 .

Department of Health. Claims of medical negligence against NHS hospital and community doctors and dentists. London: Department of Health, 1989. (HC(89)34.

\title{
Stopping steroids in polymyalgia rheumatica and giant cell arteritis
}

\author{
Treatment usually lasts for two to five years
}

Corticosteroids are mandatory in the treatment of giant cell arteritis because they relieve symptoms rapidly and reduce the incidence of complications such as blindness. ${ }^{1}$ Most clinicians also use steroids to treat polymyalgia rheumatica because although other anti-inflammatory drugs will lessen the painful symptoms, they are not as effective as steroids, and only steroids will prevent the complications of arteritis.

Patients are often apprehensive about taking steroids, and they usually want to know when the treatment may be discontinued. Both polymyalgia rheumatica and giant cell arteritis seem to be self limiting disorders; early descriptions comment on their "curability," 3 and later reports in the 1950 s suggested a duration for polymyalgia rheumatica of about five to seven years. ${ }^{45}$ In the era since the introduction of steroids the first retrospective studies in the 1970s suggested that treatment was necessary for at least two years. Fauchald et al found that only $14 \%$ of 94 patients with polymyalgia rheumatica had stopped taking steroids at 16 months, ${ }^{6}$ and Myles reported similar results (17\% at 21 months) with more than one third of 84 patients still taking steroids after four years. ${ }^{7}$ Another group found $84 \%$ still taking steroids at five years. ${ }^{8}$

In the 1980 s the pattern was similar. Ninety patients with polymyalgia rheumatica or giant cell arteritis were followed for three to 10 years; 37 had stopped taking steroids at a mean of 27 months, but 35 still needed treatment at a mean of 59 months. ${ }^{9}$ In a series of patients with giant cell arteritis with predominantly visual or neurological problems one third were found to require treatment indefinitely. ${ }^{10}$ Behn et al found that 72 of 176 patients had stopped taking steroids at a mean of 31 months. ${ }^{11}$ Another group used lifetable analysis and found that $40 \%$ of patients with polymyalgia rheumatica were likely to need treatment at four years. ${ }^{12}$ A recent French study reported that 65 of 132 patients with polymyalgia rheumatica had stopped taking steroids after a mean of $25 \cdot 7$ months and that 40 of 78 patients with giant cell arteritis had stopped taking them at 30.9 months. ${ }^{13}$ A prospective study from Cambridge found that a quarter of patients with polymyalgia rheumatica or giant cell arteritis were able to stop taking steroids by two years. ${ }^{14}$

By contrast, studies from the United States have reported a much shorter duration of the disease for both polymyalgia rheumatica ( 11 months was the median duration of treatment, and three quarters of patients had stopped taking steroids by two years) ${ }^{15}$ and giant cell arteritis (most patients had stopped taking steroids within two years). ${ }^{16}$

Interpreting the results of the studies may be difficult for the clinician dealing with an individual patient. Some groups included patients with polymyalgia rheumatica and giant cell arteritis, some included only patients with a biopsy specimen that gave a positive result for giant cell arteritis, and most studies were retrospective. The consensus view seems to be, however, that stopping treatment is feasible from two years onwards. This view is supported by some recent laboratory evidence. Dasgupta et al measured serum $\mathrm{T}$ cell subsets before and during treatment in polymyalgia rheumatica and giant cell arteritis and found a profound and selective reduction of $\mathrm{CD} 8+$ suppressor-cytotoxic cells that persisted for up to one year despite satisfactory control of the disease in terms of symptoms, erythrocyte sedimentation rate, and $\mathrm{C} \stackrel{\mathbb{Q}}{\Omega}$ reactive protein concentration. ${ }^{17}$ After two years of treatment $\overline{2}$ the numbers of CD8 + cells had returned to those found in 8 normal controls. Monitoring CD8+ cells may prove useful in deciding when steroids can be withdrawn. Other groups have 흘 not, however, found such a close association, and low $\rightleftharpoons$ numbers of $\mathrm{CD} 8+$ cells may be found in autoimmune disorders and also in some infections. ${ }^{18} 19$

What are the risks of premature withdrawal of steroids? 
The disease may be reactivated, and this may lead to complications such as blindness; but fortunately this is rare. More often activity of the disease seems to decline steadily: relapses are more likely during the initial 18 months of treatment ${ }^{1+}$ and within one year of withdrawal of steroids. ${ }^{911}$ There is no reliable method of predicting those most at risk, but arteritic relapses in patients who presented with pure polymyalgia rheumatica are unusual, ${ }^{12} 20$ although one study reported a high incidence of complications in polymyalgia rheumatica. ${ }^{21}$ We recently found that patients with both polymyalgia rheumatica and giant cell arteritis were more likely to experience relapses than those with polymyalgia rheumatica or giant cell arteritis alone. ${ }^{14}$ Men were more likely to experience complications of giant cell arteritis than women in one study, ${ }^{13}$ but women needed treatment for longer in another. ${ }^{12}$ Temporal artery biopsy does not need help in predicting outcome..$^{131+22}$

The risks of continuing treatment with steroids unnecessarily are those of steroid related complications. Between one fifth and a half of patients may experience serious side effects $^{2324}$ unless the initial dose of prednisolone is $10 \mathrm{mg}$ or less and maintenance doses of less than $7.5 \mathrm{mg}$ are used. ${ }^{82025}$ High initial doses, cumulative doses, maintenance doses, and increased duration of treatment have all been associated with increased side effects. ${ }^{12}{ }^{25}$ There is still no reliable guide to which patients are most at risk, and studies need to be done to show whether prophylactic treatment to reduce osteoporotic fracture is of value in polymyalgic rheumatica and giant cell arteritis. Azathioprine has been shown to exert a modest steroid sparing effect. ${ }^{26}$ Reduction of doses of prednisolone on alternate days once doses of less than $5 \mathrm{mg}$ are reached makes withdrawal easier, and the addition of a non-steroidal agent at this stage may reduce some of the minor muscular symptoms that patients develop as doses of steroids are reduced. Some patients, however, find it impossible to stop taking the final 2-3 mg, and this level of maintenance dose is probably safe.

In summary, patients should be warned to expect treatment for at least two years, while most should be able to stop taking steroids after four to five years. Monitoring for relapse should continue for six months to one year after stopping steroids; thereafter patients should be asked to report back urgently if arteritic symptoms occur. The risk of this happening is small and unpredictable. A few patients may need low dose treatment indefinitely.

V KYLE Lecturer in Rheumatology B L HAZELMAN

Rheumatology Research Unit, Consultant Rheumatologist

Addenbrooke's Hospital,

Cambridge CB2 2QQ

Birkhead NC, Wagener HP, Schick RM. Treatment of temporal arteritis with adrenal corticosteroids. Results of 55 cases where lesions were proven at biopsy. FAMA 1957;163:821-7. Bruce W. Senile rheumatic gout. $\mathrm{Br}$ Med f 1888;ii:811-3.

3 Hutchinson J. Diseases of the arteries No 1 . On a peculiar form of thrombotic arteritis of the aged which is sometimes productive of gangrene. Arch Surg 1890;1:323-9.

wh is sotic 1957:16:230-7.

5 Bagratuni L Prognosis in the anarthritic rheumatoid syndrome. Br Med f 1963;i:513-8.

6 Fauchald R, Rygvold O, Oystese B. Temporal arteritis and polymyalgia rheumatica. Clinical and biopsy findings. Ann Intern Med 1972;77:845-52.

Myles AB. Polymyalgia rheumatica and giant cell arteritis: a seven year study. Rheumatology and Rehabilitation 1975;14:231-5.

Coomes EN, Ellis RM, Kay AG. A prospective study of 102 patients with polymyalgia rheumatica syndrome. Rheumatology and Rehabilitation 1976;15:270-5.

Bengtsson BA, Malmwall BE. Prognosis of giant cell arteritis including temporal arteritis and polymyalgia rheumatica. Acta Med Scand 1981;209:237-45.

10 Graham E, Holland A, Avery A, Ross Russell RW. Prognosis in giant cell arteritis. Br Med $\mathcal{F}$ 1981;282:269-71.

1 Behn AR, Perera T, Myles AB. Polymyalgia rheumatica and corticosteroids: how much for how long? Ann Rheum Dis 1983;42:374-8.

Ayoub WT, Franklin CM. Torreti D. Polymyalgia rheumatica. Duration of therapy and outcome. Am $\mathcal{F}$ Med 1985;79:309-15.

13 Delecoeuillerie D, Jolly P, Cohen de Lara A, Paolaggi JB. Polymyalgia rheumatica and temporal arteritis: a retrospective analysis of prognostic features and different corticosteroid regimens arteritis: a retrospective analysis of prognostic features and dif

$\mathrm{Kyle} \mathrm{V}, \mathrm{Hazleman} \mathrm{BL}$. The clinical and laboratory course of polymyalgia rheumatica/giant cell Kyle V, Hazleman BL. The clinical and laborat
arteritis. Br f Rheumatol 1988;27 (suppl 1):7.

15 Chuang TY, Hunder GG, Ilstrup DM, Kurland LT. Polymyalgia rheumatica. A 10 year epidemiological and clinical study. Ann Intern Med 1982;67:672-80

16 Huston KA, Hunder GG. Giant cell arteritis: a clinical review. Am Heart f 1980;100:99-107

17 Dasgupta B, Duke O, Timms AM, Pitzalis C, Panayi GS. Selective depletion and activation of CD8 + lymphocytes from peripheral blood of patients with polymyalgia rheumatica and giant cell arteritis. Ann Rheum Dis 1989;48:307-11.

18 Benlarache C, Segond P, Anquier L, Bouvet JP. Decrease of the OKT8 positive T cell subset in polymvalgia rheumatica, lack of correlation with disease activity. Arthritis Rheum 1983;26: $1472-80$.

19 Elling H, Elling P. Decreased level of suppressor-cytotoxic T cells (OKT8a) in polymyalgia rheumatica and temporal arteritis. $\mathcal{F}$ Rheumatol 1985;12:306-9.

Spiera H, Davison S. Treatment of polymyalgia rheumatica. Arthritis Rheum 1982;25:120.

21 Jones JG, Hazleman BL. Prognosis and management of polymyalgia rheumatica. Ann Rheum Dis $1981 ; 40: 1-5$.

22 Vilaseca J, Gonzales A, Cid MC, Lopez-Vivancos J, Ortega A. Clinical usefulness of temporal artery biopsy. Ann Rheum Dis 1987;46:282-5.

23 Von Knorring J. Treatment and prognosis in polymyalgia rheumatica and temporal arteritis. Acte Med Scand 1979;205:429-35.

24 Fainaru M, Friedman G, Friedman B. Temporal arteritis in Israel. A review of 47 patients. I Rheumatol 1979;6:330-5.

$25 \mathrm{Kyle}$ V, Hazleman BL. Treatment of polymyalgia rheumatica (PMR) and giant cell arteritis (GCA). II. The relationship between steroid dose and steroid-associated side effects. Ann Rheum Dis 1989;48:662-6.

26 De Silva M, Hazleman BL. Azathioprine in giant cell arteritis/polymyalgia rheumatica: a double blind study. Ann Rheum Dis 1986:45:136-8.

\section{Identification of the cystic fibrosis gene}

\section{Practical implications for patients and their families}

It is only five years since the discovery of the linkage of the cystic fibrosis gene to the gene coding for the enzyme paraoxonase and the assignment of the linkage group of which cystic fibrosis is a part to chromosome $7 .^{12}$ So the recent identification of the cystic fibrosis gene itself and its most common mutation represents an extraordinary achievement by all those concerned. ${ }^{3.5}$ What are the practical implications of this advance for patients and their families?

The mutation that has been identified is not found in all patients with cystic fibrosis. It occurs in $68 \%$ of patients' chromosomes, and neither a complete genomic nor complementary DNA sequence is yet available. This mutation $(\Delta \mathrm{F} 508)$ causes the deletion of an in frame TTT triplet, which corresponds to the predicted loss of a phenylalanine residue in the specified protein. The protein itself has not been purified, although from the genetic sequence it seems to be a member of a family of transmembrane regulatory proteins.

One immediate task is to identify the remaining mutations associated with cystic fibrosis. Current estimates put the number of these additional mutations at about 10-12. At the third North American congress on cystic fibrosis held in October 1989 it was agreed to establish a consortium whereby all laboratories working on the molecular genetics of cystic fibrosis would share new information about sequences and other mutations as soon as it becomes available. The next task - once a full genetic sequence has been established - is to produce models of the disease both by transfecting the abnormal cystic fibrosis gene into epithelial cells in vitro and by constructing transgenic animal models. A third task, which awaits the purification of the protein, is the 